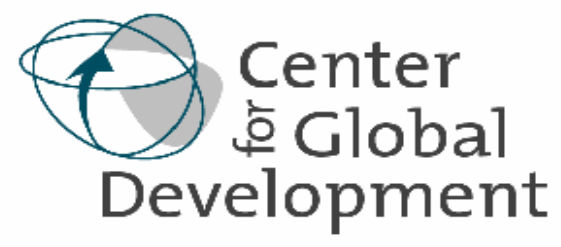

Working Paper Number 57

Aprill 2005

\begin{abstract}
AUTONOMOUS RECOVERY AND INTERNATIONAL INTERVENTION IN COMPARATIVE PERSPECTIVE
\end{abstract}

By Jeremy M. Weinstein

Abstract
There is growing recognition that significant threats to collective security
emerge not only from competition among great powers, but also from the disorder,
violence, and oppression wrought by governments (or occurring in the absence of
effective governance) across the developing world. Scholars have responded by
proposing new models of intervention-including neo-trusteeship and shared
sovereignty-that respond to these failures of governance. But these calls for
intervention rest on two underlying assumptions that have escaped serious
consideration: the idea the countries cannot recover from conflict on their own and
the argument that intervention is the best strategy for state-building. In this article,
I define and describe a process of autonomous recovery in which states achieve a
lasting peace, a systematic reduction in violence, and post-war political and
economic development in the absence of international intervention. I offer a series
of theoretical reasons to take it seriously and use case studies of recovery in
Uganda, Eritrea, and Somalia to demonstrate how it works in practice. I conclude by
identifying three tradeoffs-for the country on the receiving end of intervention-that
policymakers confront when weighing whether and how to respond to internal
conflict.




\title{
AUTONOMOUS RECOVERY AND INTERNATIONAL INTERVENTION IN COMPARATIVE Perspective ${ }^{1}$
}

\author{
Jeremy M. Weinstein \\ Assistant Professor \\ Department of Political Science \\ Stanford University \\ jweinst@stanford.edu \\ Non-Resident Fellow \\ Center for Global Development
}

\footnotetext{
${ }^{1}$ I wish to thank James Fearon, Page Fortna, Stephen Krasner, David Laitin, Terry Moe, Ken Schultz, Jack Snyder, Michael Tomz, Jonathan Wand, Barry Weingast and participants in seminars at Oxford and Stanford Universities for helpful comments. I also acknowledge the research assistance of Milan Vaishnav, who provided support at the earliest stages of my thinking, and Jeffrey Shen, who helped me bring the project to its conclusion.
} 
The plight of weak, failing, and failed states has set off a fire alarm in the foreign policy establishment and the academic community. ${ }^{2}$ There is growing recognition that significant threats to collective security emerge not only from competition among great powers, but also from the disorder, violence, and oppression wrought by governments (or occurring in the absence of effective governance) across the developing world. ${ }^{3}$

Since September 11, it is difficult to imagine a clearer, less controversial example than Afghanistan. Geopolitical considerations led to arming of domestic and foreign militant groups in the 1980s and the subsequent disregard of their dismantling of the Afghan state. As Afghanistan descended into violence and chaos, the Taliban and their foreign backers looked like saviors to the Afghan people, even as they provided a new home base to the Al-Qaeda network.

But Afghanistan is only the most obvious example - because the consequences of its internal instability already have been felt inside the United States. In West Africa, Charles Taylor took advantage of a power vacuum in Liberia to install an authoritarian regime and incite a decade-long civil war in neighboring Sierra Leone. Central Asia has become central to the global market in illicit small arms and light weapons. The collapse of Haiti's most recent government - following a major U.S. intervention in the mid-1990s - heralds a return to the disconcerting images of Haitian refugees on rafts making their way toward U.S. shores.

With awareness of the governance failures of developing countries at an all-time high captured in the popular press, debated in the pages of influential periodicals, and hotly contested in the presidential campaign - policymakers have been spurred to action. Post-conflict reconstruction is the foreign policy issue du jour in Washington, DC and across foreign capitals. ${ }^{4}$ Two major think tanks have sponsored high-level commissions on the subject. ${ }^{5}$ No fewer than ten bills intended to improve U.S. post-conflict capacity have been introduced in Congress. ${ }^{6}$ Just before the election, the State Department established a new office for reconstruction, reporting directly to the Secretary of State. ${ }^{7}$ The consensus of the policy community is that the United States must be prepared to play a more active role in state-building efforts.

\footnotetext{
${ }^{2}$ Three articles on the subject have been published in Foreign Affairs in as many years. See Sebastian Mallaby, “The Reluctant Imperialist: Terrorism, Failed States, the Case for American Empire,” Foreign Affairs, (March/April 2002); Chester Crocker, "Engaging Failing States,” Foreign Affairs, (September/October 2003); Stuart Eizenstat, John Edward Porter, and Jeremy Weinstein, "Rebuilding Weak States," Foreign Affairs, (January/February 2005).

${ }^{3}$ See, “A more secure world: our shared responsibility," the Report of the Secretary General's High-Level Panel on Threats, Challenge, and Change, 2004.

${ }^{4}$ See Eizenstat et. al, "Rebuilding Weak States."

${ }^{5}$ See Center for Strategic and International Studies (CSIS), "Play to Win,” the final report of the Bi-Partisan Commission on Post-Conflict Reconstruction, January 2003. The Center for Global Development (CGD) sponsored the Commission on Weak States and US National Security. See CGD, "On the Brink: Weak States and US National Security,” June 2004.

${ }^{6}$ The most important of these bills was introduced by Senators Joseph Biden and Richard Lugar in February 2004. See "Stabilization and Reconstruction Civilian Management Act of 2004," (S. 2127).

${ }^{7}$ See the press release announcing the launch of the office, http://www.state.gov/r/pa/prs/ps/2004/36558.htm.
} 
Scholars are jumping into the fray as well. In his new book, Francis Fukuyama argues that state-building - which he defines as creating new government institutions or strengthening existing ones - is a major foreign policy challenge because weak or failed states are "the source of many of the world's most serious problems." ${ }^{8}$ While he accepts the notion that international actors do not know a great deal about how best to transfer institutional knowledge to poorly governed states, he nonetheless concludes that state-building - as opposed to cutting back the state - should be at the top of the international agenda.

On the pages of International Security, political scientists have been grappling with the question of how the international community should think about intervention in collapsed states. James Fearon and David Laitin propose a model of neo-trusteeship to deal with problems of recruitment, coordination, accountability, and exit in transitional administration. ${ }^{9}$ Critical to their proposal is a call for the recruitment of "lead states" with significant national security or economic interests in a collapsed state to run interventions, and for an exit strategy that focuses squarely on developing local ownership for missions through the establishment of taxation capacity. Stephen Krasner offers his own vision of governance for weak and failed states - one which relies on the idea of "shared sovereignty" contracts. ${ }^{10}$ These contracts would create joint authority structures in specific issue areas, such as natural resource management, combining international actors with domestic institutions.

Surprisingly, two underlying assumptions of these models remain unexplored in debates across both the policy and academic communities. First, policymakers and scholars seem to agree that collapsed states will not emerge from internal crises on their own. Second, analysts accept the proposition that intervention - in the form of mediation, peacemaking, and peacekeeping - is a necessary, if not the key, instrument for reversing the political and economic decline of poorly governed states.

In this article, I bring a critical eye to the assumptions that underlie the new state-building consensus. I ask a series of questions that ought to inform debates about how the U.S. and other global powers should respond to the collapse of states. What are the prospects for autonomous recovery in weak, failing, and failed states? What forms of governance are likely to emerge in the absence of international intervention? What lessons do cases of autonomous recovery offer to policymakers concerned about the weakness of governments in the developing world?

\footnotetext{
${ }^{8}$ Fukuyama offers a useful critique of the state-building literature, which he argues conflates concepts of state "scope" and state "strength." See Francis Fukuyama, State-Building: Governance and World Order in the $21^{\text {st }}$ Century (Ithaca: Cornell University Press, 2004).

${ }^{9}$ Recognizing that current multilateral efforts are hamstrung by a host of pathologies, Fearon and Laitin offer a model of "post-modern imperialism.” In particular they offer creative proposals to address four major challenges that bedevil post-conflict missions: the recruitment of lead states, the coordination of activities in post-conflict environments, the accountability of those that intervene, and the problem of exit. See James Fearon and David Laitin, "Neo-Trusteeship and the Problem of Weak States," International Security, Vol. 28, No. 4 (Spring 2004), p. 5-43.

${ }^{10}$ Krasner also calls for alternative institutional arrangements including the return of trusteeships that actively engage external actors in domestic governance on a quasi-permanent basis. See Stephen Krasner, "Sharing Sovereignty: New Institutions for Collapsed and Failing States,” International Security, Vol. 29, No. 2 (Fall 2004), p. 85-120.
} 
The article proceeds as follows. First, I discuss in greater detail conventional perspectives on the problem of collapsed states and the appropriate forms of international response. Second, I define and describe a process of autonomous recovery in which states achieve a lasting peace, a systematic reduction in violence, and post-war political and economic development in the absence of international intervention. I offer a series of theoretical reasons to take it seriously and use case studies of recovery in Uganda, Eritrea, and Somalia to demonstrate how it works in practice.

Third, I step into the shoes of policymakers faced with the task of resolving conflict and building states in the developing world. I identify three tradeoffs that policymakers confront when comparing the benefits and costs of intervention as compared to non-intervention. Specifically, I argue that while external intervention offers the possibility of stopping mass killing in the short-term, it may stunt processes of internal, institutional change that warfare reflects. Autonomous recovery elevates strong leaders who are able to secure the resources necessary to win wars and have the power to implement far-reaching policy reforms, but it favors strong fighters who tend not to embrace power-sharing arrangements of the type favored by international actors. Finally, international intervention relies on largely discredited tools of external influence including aid, conditionality, and sanctions, while autonomous recovery offers internal incentives for institution-building when the conditions are right.

Recognizing that policymakers will often choose intervention over non-intervention for a host of legitimate reasons, I conclude with some key lessons we can draw from countries that have experienced autonomous recovery to inform international efforts that seek to prevent state collapse, bring wars to an end, and rebuild countries after conflict. In particular, I argue that the international community would be wise to develop a new strategy for ending civil wars and reconstituting states - one that identifies and supports competent, legitimate military actors to help them win and then constrains these victors to prevent authoritarian decay from taking root.

The arguments I advance in this article can be easily misinterpreted. One erroneous conclusion that could be drawn from my analysis of autonomous recovery is that external efforts to build states should never be launched. Such a conclusion is neither warranted by the evidence, nor advanced in this article, nor realistic in a climate of growing acceptance for the international community's "responsibility to protect." Often, international actors make decisions based on a purely moral imperative to bring human rights abuses, mass killing, and genocide to an end. Moreover, the conditions under which autonomous recovery is likely to occur are rare and difficult to create. So my analysis should be read with a view toward identifying and understanding internal processes of change that give rise to successful state-building, the conditions under which these internal mechanisms are likely to work, and the lessons international actors can draw from autonomous recovery for efforts to bring conflict to an end. Although it may be difficult to accept, one of the key lessons is that sometimes it makes sense not to intervene, or to intervene actively on behalf of one side. 


\section{The ConVentional WisDom}

Weak, failing, and failed states litter the landscape of the developing world. They are characterized by inadequate, abusive, or incompetent governments that are incapable of (or unwilling to) provide physical security, deliver public goods such as education and health care, and protect basic human rights.

The U.S. government's State Failure Task Force identified 136 occurrences of statefailure in the period between 1955 and 1998. Operationalized as one of four kinds of internal crisis - revolutionary war, ethnic war, adverse regime change, and genocide - the task force found that, between 20 and 30 percent of countries were in "failure" during the 1990s. ${ }^{11}$ With a narrower focus on civil war, James Fearon and David Laitin found that between 15 and 25 countries have been enmeshed in conflict, at any single point in time, since the 1980s. ${ }^{12}$

Global powers worry now about the consequences of domestic political disorder for international security. ${ }^{13}$ The rise of nuclear weapons has made conflict between the great powers highly unlikely, turning attention toward new threats that emerge from states previously seen as strategically unimportant. Some of these effects can be seen as bad "externalities" that result from the intersection of technological change and poor governance. ${ }^{14}$ The threat of catastrophic terrorism using WMD, the growth of drug smuggling networks, and the spread of disease fit into this category. But collective security also is threatened by "spillover" effects from domestic disorder in which protracted civil wars destabilize entire regions - spreading combatants, refugees, and weapons across their borders.

While humanitarian motivations undoubtedly play an important role, it is recognition of these "public bads" that is behind increasing calls for global action to respond to the collapse of governments. And the form that action should take is shaped by a commonly-held set of beliefs elaborated by the World Bank:

"Countries abandoned by the international development community show few signs of autonomous recovery, and meanwhile their populations suffer severe deprivation. Such countries are also at risk of "state failure," with its evident adverse effects, both regional and global. Very weak policies, institutions, and governance lock countries into poverty,

\footnotetext{
${ }^{11}$ See the State Failure Task Force Report: Phase III Findings (McLean, VA: Science Applications International Corporation, September 30, 2000).

${ }^{12}$ Fearon and Laitin define civil wars as conflicts among organized groups within a state for state or regional power that kill at least 1000 individuals over their course, with at least 100 dead on each side, and an average of at least 100 killed per year. See James Fearon and David Laitin, "Ethnicity, Insurgency, and Civil War,” American Political Science Review, Vol. 97, No. 1, (February 2003), p. 75-90.

${ }^{13}$ See, in particular, CGD, "On the Brink: Weak States and US National Security”; Crocker, "Engaging Failing States”; and UN, "A more secure world: our shared responsibility."

${ }^{14}$ Fearon and Laitin point especially to the collective action problems that civil wars raise for developed countries. Given the dangers posed by collapsed states and rouge regimes, all would benefit from stability, order, and responsible governments in the periphery. But the costs of providing effective assistance to rebuild weak and failed governments may exceed the benefits for any one global power. See Fearon and Laitin, "Neo-Trusteeship and the Problem of Weak States.”
} 
economic decline, and dependence on primary commodities_-major risk factors in state breakdown."15

It is widely believed that multilateral intervention can interrupt this conflict trap and set countries on a path toward postwar economic and political development. ${ }^{16}$ International intervention may stabilize the security situation, change incentives on the ground, provide guarantees that enable military actors to commit to a peace process, and deliver the much-needed resources and capacity to begin a rebuilding effort. ${ }^{17}$

There is some evidence that multilateral intervention works and it is seen as costeffective. ${ }^{18}$ Statistical evidence suggests that UN peacekeeping is associated with successful democratization processes after civil war, and multilateral enforcement operations are effective at ending the violence. ${ }^{19}$ Related research suggests that consent-based operations, rather than enforcement missions, more effectively maintain the peace. ${ }^{20}$ Some argue that external military intervention offers the biggest bang for the buck in reducing the incidence of conflict, with the benefits of a stable peace far outweighing the costs of intervention. ${ }^{21}$

\footnotetext{
${ }^{15}$ World Bank, "World Bank Group Work in Low-Income Countries Under Stress: A Task Force Report," September 2002, p. iv.

${ }^{16}$ In the paper, intervention refers to two distinct types of action: international efforts to stop on-going wars and missions to sustain a negotiated peace agreement. While it is possible that such interventions may have different effects, for the purposes of comparison with non-intervention, I lump them together.

${ }^{17}$ Barbara Walter offered the definitive theoretical argument about the role of the international community in providing external security guarantees, making it possible for domestic actors to disarm and demobilize. See Barbara Walter, Committing to Peace: The Successful Settlement of Civil Wars (Princeton, NJ: Princeton University Press, 2001).

${ }^{18}$ One approach employs qualitative, comparative case studies to assess the effectiveness of UN peacekeeping missions. On issues of how to evaluate UN efforts, see George Downs and Stephen Stedman, "Evaluation Issues in Peace Implementation,” in Stephen Stedman, Donald Rothchild, and Elizabeth Cousens (eds.), Ending Civil Wars: The Implementation of Peace Agreements (Boulder, CO: Lynne Rienner, 2002).
}

${ }^{19}$ A second approach utilizes statistical methods to estimate the effects of UN peacekeeping missions on democratization and post-war stability. A major contribution in this area is Michael Doyle and Nicholas Sambanis, "International Peacebuilding: A Theoretical and Quantitative Analysis," American Political Science Review, Vol. 94 (December 2000), p. 779-801. Statistical work in this area, while making significant advances, faces a series of difficult hurdles. The most obvious is that peacekeeping operations are not applied to countries at random; as a consequence, without quality instruments for peacekeeping operations, it is difficult to distinguish the effect of peacekeeping from other factors that may differentiate countries that receive an intervention from those that do not. In addition, significant debates exist about how best to measure success. Current data allow measurements of stability that extend two, five, and perhaps ten years into the future; realistically, a stable peace is one that survives the departure of UN peacekeepers for an extended period of time. With most of the operations conducted in the 1990s, more stringent definitions of success would lead to the dropping of too many observations.

${ }^{20}$ See Page Fortna, “Forever Hold Your Peace? An Assessment of Peacekeeping in Civil Wars,” Unpublished Manuscript, Columbia University, 2003.

${ }^{21}$ For the Copenhagen Consensus Project, Paul Collier and Anke Hoeffler weigh the costs and benefits of activities designed to prevent conflict (such as aid to weak governments) against those of multilateral interventions organized to rebuild governments in the aftermath of war. See Paul Collier and Anke Hoeffler, "Conflicts," in Bjorn Lomborg, Global Crises, Global Solutions (Cambridge, UK: Cambridge University Press, forthcoming). 
So it is no surprise then, that the debates among scholars have focused more on the form that intervention should take, rather than the question of whether to intervene at all. Such discussions, however, should begin with a specification of the objectives to be achieved. With the construction of sustainable, functioning institutions as the goalpost, I argue that nonintervention deserves a second look.

\section{Moving the Goalposts}

Institutions - defined as "a set of humanly devised behavioral rules that govern and shape the interaction of human beings, in part by helping them to form expectations of what others will do" - are fundamental to the development process, and not merely a byproduct of prosperity. ${ }^{22}$ Institutions take many forms, and often include protections for basic property rights, constraints on the abuse of power, and mechanisms for encouraging participation and managing conflict through peaceful means. The quality of these institutions is seen as critical to the growth process - providing strong incentives for investment and enabling governments to respond to shocks that originate in the international system. ${ }^{23}$ In the absence of such institutions, it is hard to imagine that a stable peace (even one guaranteed, at least initially, by external actors) can survive.

Breaking countries free from the conflict trap requires the development of a particular form of institution - the self-enforcing constitution. ${ }^{24}$ A self-enforcing constitution must meet two conditions. First, no significant group of citizens or parties out of power can be willing to attempt to subvert power or secede. The set of rules must provide strong incentives for those outside of power to work within the system. Second, those in power must have sufficiently strong incentives to honor the rules, even if doing so may cost them their position in power. With a self-enforcing constitution in place, the state can make a credible commitment to protect a citizen's rights and assets in exchange for the consent of citizens to be governed.

This focus on the need to build sustainable institutions reveals an underlying challenge that makes multilateral intervention so difficult. The international community has developed mechanisms to supply the right institutions, finance necessary policy reforms, and deliver the blueprints for participatory and transparent governance. But institutions themselves are much more than bureaucracy or a set of rules recorded on paper. They are the result of a bargain $-\mathrm{a}$ social compact between rulers and constituents - and it is the nature of that compact that shapes

\footnotetext{
${ }^{22}$ For a review on the literature linking institutions to economic growth, see Justin Lin and Jeffrey Nugent, "Instutitions and Economic Development," in J. Behrman and T.N. Srinivasan, Handbook of Economic Development Vol. 3A (North-Holland, Amsterdam, 1995).

${ }^{23}$ For example, see Daron Acemoglu, James Robinson, and Simon Johnson, “The Colonial Origins of Comparative Development: An Empirical Investigation,” American Economic Review Vol. 91, No. 5, (December 2001), p. 13691401; Dani Rodrik, "Where Did all the Growth Go? External Shocks, Social Conflict, and Growth Collapses,” Journal of Economic Growth Vol. 4, No. 4 (December 1999).

${ }^{24}$ A classic statement on the self-enforcing constitution is Douglass North and Barry Weingast, "Constitutions and Commitment: The Evolution of Institutions Governing Public Choice in Seventeenth Century England,” Journal of Economic History XLIX (1989), p. 803-832. See also Barry Weingast, "Self-Enforcing Constitutions: With an Application to Democratic Stability in America’s First Century,” Unpublished Manuscript, Stanford University, October 2004.
} 
the existence, structure, and membership of the institutions of government. ${ }^{25}$ For this reason alone, it makes sense to look at the types of institutions that emerge in the absence of international intervention.

\section{Autonomous Recovery}

I define autonomous recovery as a process through which countries achieve a lasting peace, a systematic reduction in violence, and postwar political and economic development in the absence of international intervention. It can be usefully contrasted with aided recovery, a process in which international intervention plays a significant role in bringing war to an end, maintaining or guaranteeing a negotiated settlement, and assisting in the recovery process.

In this section, I discuss two intuitions central to the concept of autonomous recovery. The first is that war produces peace. The second, and perhaps more controversial, is that war generates stable, self-sustaining, and representative institutional arrangements. I describe the logic underlying each intuition and provide some empirical evidence in favor of their plausibility.

\section{War Produces Peace: The Logic}

The logic behind the first intuition was famously laid out in a controversial article in Foreign Affairs. $^{26}$ On the heels of UN peacekeeping disasters in Somalia, Rwanda, and Bosnia, Luttwak reminded readers of an "unpleasant truth." War has the potential to actually resolve political conflict and lead to peace. In particular, the absence of international intervention allows conflict to run its "natural course." By this logic, war comes to an end when one group is strong enough to win decisively, or when both groups are sufficiently exhausted that they become willing to accommodate one another.

Cease-fires and negotiated settlements, on the other hand, allow belligerents to reconstitute their forces, especially if there is uncertainty about the durability of the agreement (because of the unobservable intentions of either party or uncertainty about the commitment of external actors to guarantee the peace). In effect, intervention serves to freeze unstable distributions of power and to provide a respite from hostilities for groups that are intent on continuing the conflict when the international community departs. This is a particular problem because intervention forces tend to attempt to intervene impartially, neither providing sufficient force to help one side win, nor committing to stay long enough to allow antipathies that exist between fighting groups to be overcome.

Luttwak shares the stage with other scholars who have advanced similar claims. Indeed, more than ten years ago, Wagner argued that negotiated settlements create internal balance-of-

\footnotetext{
25 The claim that institutions depend on a social compact between rulers and constituents does not logically imply that such institutions can only be forged in the absence of international intervention. United Nations missions increasingly emphasize mechanisms to generate local buy-in, such as the Loya Jirga in Afghanistan. A critical unanswered question is the extent to which such mechanisms generate self-sustaining institutions.

${ }^{26}$ See Edward Luttwak, “Give War a Chance,” Foreign Affairs Vol. 78, No. 4 (July/August 1999).
} 
power situations in which the new government has a difficult time operating. ${ }^{27}$ Military victories, on the other hand, create the conditions in which the winning party is better able to consolidate power and shape the postwar trajectory. With one side too weak to influence the political debate or to restart a war, the winner is capable of mounting relatively unified action and exhibiting a centralized control over resources.

\section{War Produces Peace: Some Evidence}

It turns out that the claim of war producing peace is supported by much of the quantitative evidence on the determinants of successful peacebuilding. In an influential article on the effectiveness of negotiated settlements - the first major statistical work on the determinants of civil war resolution - Licklider reported a strong statistical correlation between military victories and a stable peace. ${ }^{28}$ Civil wars did not recur in $85 \%$ of the countries that experienced a military victory, while war resumed in $50 \%$ of the conflicts settled by means of negotiation. He took this as confirmation of what he called the "Wagner hypothesis."

Subsequent statistical work confirms Licklider's early findings. Fortna records a significant impact of military victory on the durability of peace; the hazard for another war drops by over $80 \%$ when there is a decisive military outcome. ${ }^{29}$ This is a larger effect than the $32 \%$ drop in the risk of war recorded for the presence of UN peacekeepers. Toft reports that wars ended by military victory are twice as likely to remain settled than those ended by negotiated settlement or ceasefire. In particular, rebel victories exhibit the highest degree of stability. ${ }^{30}$ These results again fit with the logic provided earlier-namely, that decisive victories have a transformative effect, weakening the capacity or will of opposing parties to reignite conflict.

Africa provides a unique laboratory to probe further the plausibility of this intuition because of its high incidence of civil war and the perceived reluctance of the United Nations to mount interventions on the continent. Table 1 provides a list of civil wars in Africa after 1975, when anti-colonial wars came to an end. ${ }^{31}$ The conflicts are separated by whether an external intervention was mounted by the UN or not. The table demonstrates clearly that a significant number of cases of non-intervention do exist, providing a useful basis for some preliminary empirical tests. ${ }^{32}$

\footnotetext{
${ }^{27}$ Robert Harrison Wagner, “The Causes of Peace,” in Roy Licklider (ed.), Stopping the Killing (New York: New York University Press, 1993). For a slightly different mechanism, see Monica Toft, "Peace Through Victory: The Durable Settlement of Civil Wars,” Unpublished Manuscript, Harvard University, 2003.

${ }^{28}$ Roy Licklider, “The Consequences of Negotiated Settlements in Civil Wars, 1945-1993,” American Political Science Review Vol. 89, No. 3 (September 1995), p. 681-690.

${ }^{29}$ See Fortna, “Forever Hold Your Peace.”

30 Toft, "Peace Through Victory."

31 This data comes from the Doyle and Sambanis (2000) dataset of civil wars.

${ }^{32}$ A critical issue in evaluating the effectiveness of UN interventions is an assessment of in which countries the UN elects to intervene. Interventions are not mounted randomly. It may be the case that the UN takes on the most difficult cases, or that the risk-averse nature of contributing nations leads the Security Council to authorize missions to easier destinations. For a substantive analysis of this issue, see Michael Gilligan and Stephen Stedman, "Where Do the Peacekeepers Go?” International Studies Review Vol. 5, No. 4 (2003), p. 37-54. Gilligan and Stedman find that while the number of deaths in a civil war is positively associated with the likelihood of an intervention, the UN
} 
(Insert Table 1)

Table 2 examines the variation in war outcomes in Africa during the same period. Using a strict definition of a stable peace - war does not recur within 10 years of the conflict coming to an end - the data confirm Licklider's earlier findings. In the absence of a UN intervention, 46\% of civil wars do not recur. When the UN gets involved, only a quarter of wars do not resume. Importantly, neither intervention nor non-intervention appears particularly well-suited to reducing low-levels of political violence which, while they do not rise to the level of civil war, nonetheless impose significant costs on political stability and the prospects for development.

\section{(Insert Table 2)}

A second finding emerges from this quick look at the African data. The evidence suggests that UN intervention makes rebel victories substantially less likely. ${ }^{33}$ Clearly, the involvement of external actors favors negotiated settlements over military victories, but as we turn to the cases in the next section, the fact that UN interventions have a particular bias against rebel victories may emerge as a cause of concern.

\section{War Generates Institutions: The Logic}

In making a case for autonomous recovery, it is not sufficient to demonstrate that war produces a more stable, durable peace. If policymakers are to be convinced that, under some conditions, non-intervention actually trumps outside involvement, it is essential to show that war generates stable, self-sustaining, and representative institutions of government as well. While the proposition may be met initially with skepticism, a brief tour through the history of European state formation provides a measure of immediate credibility to the argument. ${ }^{34}$

Few would disagree that, in the famous words of Clausewitz, war is politics continued by other means. With an eye toward how states form, war can be seen usefully as a healthy competition between groups to be the monopoly provider of public goods. It places competing claims to sovereignty in direct conflict with one another and relies on the process of war-making to separate out those groups that can mobilize resources from those incapable of turning rhetorical claims into power.

also acts with considerations of power and risk in mind: in particular, the UN is more likely to mount an intervention in weak states with small armies.

33 This finding is not terribly surprising, as the United Nations tends to intervene at the invitation of governments. Nontheless, as the next section will demonstrate, rebel groups are sometimes in a better position to reform and reconstruct institutions of government.

${ }^{34}$ Wantchekon reviews the European state-building literature to advance the claim that democratic institutions can emerge from chaos. His model depends, however, on the mediation of an impartial and neutral outside force, such as the United Nations. My argument, while building on the same theoretical tradition, suggests that such institutions can develop even in the absence of an outside force. See Leonard Wantchekon, "The Paradox of 'Warlord' Democracy: A Theoretical Investigation,” American Political Science Review Vol. 98, No. 1 (February 2004), p. 1734. 
European state builders fought wars to secure territories within which they could enjoy the economic benefits of unrivaled power - the right to collect taxes and access sources of credit. $^{35}$ Their goal was to check or overcome outside competitors and, according to Tilly, "to monopolize the means of violence within a delimited territory adjacent to a power holder's base.”36 At its root, the process was one in which leaders extended the authority of the state and projected its power outside of their base. An inability to project power is the affliction most state builders in the developing world still confront. ${ }^{37}$

Projecting power and extending authority requires challenging those who would emerge as rivals for power. State builders in Europe encountered these rivals and sought to defeat them or co-opt them, playing a "mixed strategy" that involved "eliminating, subjugating, dividing, conquering, cajoling, and buying" - whatever it took to pacify opposition and establish an unqualified monopoly over the means of violence. ${ }^{38}$ Eventually, two expensive but effective strategies were employed to rule in these new territories: the establishment of officials at the local level and the creation of police forces subordinate to the center, distinct from the armies designed for war.

But the establishment of these state institutions to consolidate power did not result from intentional state building efforts. Rather, they were by-products of the war-making process - the interaction among military conflict, extraction, and capital accumulation. ${ }^{39}$ Scholars of European state formation argue that war itself generates bureaucratic capacity, and that institutions of government in Europe are largely the "organizational residue” of processes undertaken to fight battles. $^{40}$

At the same time that war generates new bureaucratic capacity, the process of mobilizing people to fight provides an opportunity to reshape identities as well. Often, this reshaping of identity pits one group against another in a way that feeds into continued conflict. The literature

\footnotetext{
${ }^{35}$ See Charles Tilly, Capital, Coercion, and European States (Cambridge, MA: Basil Blackwell, 1990); Charles Tilly, 1999, "War-Making and State-Making as Organized Crime,” in Peter Evans, Diethrich Rueschmeyer, and Theda Skocpol (eds.), Bringing the State Back In (Cambridge: Cambridge University Press, 1999).

36 Tilly, “War-Making and State-Making as Organized Crime,” p. 172.

${ }^{37}$ Herbst argues that the fundamental problem confronting African leaders was (and continues to be) how to extend power over vast, inhospitable territories with low population densities. See Jeffrey Herbst, States and Power in Africa: Comparative Lessons in Authority and Control (Princeton, NJ: Princeton University Press, 2000).

38 Tilly, “War-Making and State-Making as Organized Crime,” p. 175.

${ }^{39}$ More recent debates focus less on the impact of war-making per se, but rather on how the costs of war-making varied across European states, and how preexisting local institutions shaped the nature of the states that emerged from conflict. See Brian Downing, The Military Revolution and Political Change: Origins of Democracy and Autocracy in Early Modern Europe (Princeton, NJ: Princeton University Press, 1992); Thomas Ertman, Birth of the Leviathan: Building States and Regimes in Medieval and Early Modern Europe (Cambridge, UK: Cambridge University Press, 1997).

${ }^{40}$ It is worth noting that Tilly's work has generated a healthy historical debate about whether states in other regions have followed the European path to consolidation. A notable book on this topic argues that the Ottoman empire followed an alternative path in which warfare was kept in check as central bureaucrats negotiated to engage bandits in the process of state-building. See Karen Barkey, Bandits and Bureaucrats: The Ottoman Route to State Centralization (Ithaca, NY: Cornell University Press, 1994).
} 
on ethnic violence is replete with references to elite manipulation of ethnic identities as part of the war-making process. ${ }^{41}$ But massive social change can also reconstitute identities in a way that overcomes preexisting local cleavages. ${ }^{42}$ The logistical requirements of warfare - to recruit and retain individual participants over time - demand that leaders develop a mobilization strategy sufficient to fill the ranks. The construction of national identities, or at least supraethnic identities, is often central to this effort as leaders from small ethnic groups attempt to build a base large enough to compete for power.

Finally, the story of European state formation also supports the idea that war itself generates strong incentives for rulers to secure the consent of the governed and build representative institutions. The extraction of capital by rulers - a process deemed so critical to the fighting of wars - often generated popular resistance. In this back-and-forth between rulers and the holders of wealth over access to capital, the "organizational residue" of government institutions came to include concessions of protections, rights, and constraints on the actions of the authorities. Revenue was exchanged for rights in a bargain that tied rulers and constituents together in institutions that survived the war-making process.

The establishment of representative institutions depended in important ways on the degree to which rulers were economically dependent on taxpayers for revenues to fight their wars. North and Weingast, in their study of the origins of constitutional arrangements in England after the Glorious Revolution, also link the economic dependence of rulers to the establishment of representative institutions. ${ }^{43}$ The Crown gave taxpayers a voice in Parliament and a credible commitment to uphold property rights - in exchange for the continued right to tax at a reasonable level. While war-making was not central to their story of democratic expansion, the revenue imperative of the Crown made reshaping institutions and constraining the power of the monarchy a rational strategy to improve the bottom line. ${ }^{44}$

\section{In the Absence of War}

The process of state formation in Europe lends credibility to the intuition that warmaking can generate stable, self-sustaining, and representative institutions of government. But what happens in the absence of war? One only need turn to the literature on state formation in Africa to find evidence in support of the flip-side of our intuition - that states formed in the absence of war develop weaker institutions of government.

\footnotetext{
${ }^{41}$ For a review of the literature on ethnic violence, see Stuart Kaufman, Modern Hatreds: The Symbolic Politics of Ethnic War (Ithaca, NY: Cornell University Press, 2001), Chapter 1.

${ }^{42}$ For an example of the reshaping of identities in war, see Elisabeth Wood, Insurgent Collective Action and Civil War in El Salvador (Cambridge, UK: Cambridge University Press, 2003).

${ }^{43}$ See North and Weingast, "Constitutions and Commitment.”

${ }^{44}$ See also, Margaret Levi, “Death and Taxes: Extractive Equality and the Development of Democratic Institutions,” in Ian Shapiro and Casiano Hacker-Corden (eds.), Democracy’s Value (Cambridge, UK: Cambridge University Press, 1999)
} 
Jackson and Rosberg were the first to highlight the glaring gap between empirical and juridical sovereignty in Africa's post-colonial states. ${ }^{45}$ While statehood previously depended on an independent, effective government that controlled territory, rapid decolonization produced a set of states in which independence was guaranteed by the international system, rather than earned through a demonstration of empirical power and authority. Jackson later coined the term "quasi-states" to refer to these governments which, because they have never undergone a statebuilding process, lack the ability to provide public goods for their citizens. ${ }^{46}$

With no serious threat to state survival emanating from the international system, African governments were less likely to engage in the costly process of extraction by building tax systems. ${ }^{47}$ Moreover, with massive infusions of foreign aid from Cold War patrons and international organizations, African governments faced a much weaker domestic revenue imperative. The sorts of bargains struck by European state builders - compacts which exchanged accountability for revenue - were never forced on African governments.

Under what conditions is a process of autonomous recovery likely to occur in Africa? When might the war-making leads to state-making trajectory produce stable, self-sustaining, and representative institutions in weak states? The literature makes the basic conditions clear. For war-making to lead to state-making, there must be a significant threat to the survival of the group or state, a strong domestic revenue imperative, and no external means to reduce the cost of fighting for survival. Importantly, some of the best and most surprising post-conflict performers in Africa in the 1990s fit exactly this mold. ${ }^{48}$

\section{War Generates Institutions: Some Evidence}

We turn again to Africa - the continent which faces the most difficult challenges of statebuilding - as our laboratory. While many developing countries have experienced surging growth in the era of globalization, generally Africa has been left behind, mired in a situation of abject poverty and violence. Yet a small number of African countries have emerged from conflict and not returned. Still fewer have capitalized on a period of stable peace to regenerate process of economic growth and reshape their institutions of government.

It is to some of these cases that we look for evidence of how war-making contributes to state-building. Uganda, which experienced the benefits of a rebel victory; Eritrea, the only country to successfully secede in the post-colonial period and; Somalia, which rebuilt effective

\footnotetext{
${ }^{45}$ Robert Jackson and Carl Rosberg, "Why Africa’s Weak States Persist: The Empirical and Juridical in Statehood,” World Politics Vol. 35, No. 1 (October 1982), p. 1-24.

${ }^{46}$ Robert Jackson, Quasi-States: Sovereignty, International Relations, and the Third World (Cambridge, UK: Cambridge University Press, 1990).

47 See Herbst States and Power in Africa.

${ }^{48}$ A small number of African countries experienced significant economic growth in the 1990s without experiencing a war. Botswana and Mauritius, in particular, have been among Africa's best economic performers since independence and neither has faced internal conflict. But on a continent in which more than one third of the countries consistently confront civil war, finding paths out of conflict toward growth is a fundamental issue.
} 
sub-state structures after the UN pulled out, provide some support for our intuition that war itself helps to generate good institutions.

State-building, I argue, follows a similar logic despite the many differences between these three cases including the length of the war, the purposes for which it was fought, the type of regime the opponents faced, and the ethnic make-up of the country. The argument thus emerges from the method of agreement: if it is convincing for three countries so distinct in all but the experience of war, the emergence of strong factions that secured the consent of noncombatants, and the formation of institutions in the absence of external support, it should be more persuasive given their differences. ${ }^{49}$

\section{Byproducts of Rebellion}

When Yoweri Museveni led his National Resistance Movement (NRM) to victory in January 1986, few believed that his guerrilla government would survive. Uganda had been the symbol of Africa's disasters in the 1970s and early 1980s. Only six years after independence in 1966, Prime Minister Milton Obote abolished the country's democratic constitution. Five years later Obote was overthrown in a coup led by Idi Amin, who quickly became the poster-child for African dictators. He destroyed the economy by expelling the Asian population, and with them, much of the business sector; he also unleashed a period of killing in which somewhere between 100,000 and 500,000 people were summarily put to death. Amin's government collapsed after he occupied a small piece of Tanzanian territory, triggering a military response from Uganda's neighbor. But the three governments that followed were short-lived, and after a disputed election that returned Obote to power in 1981, a civil war ensued. This period of political chaos devastated the Ugandan economy, with per-capita GDP declining by $40 \%$ in 15 years. ${ }^{50}$

So it comes as a surprise to many that Uganda is now seen as "the main example of successful African post-conflict recovery.”51 Since Museveni captured power in 1986, Uganda has enjoyed a period of relative political stability. The NRM's guerrilla army - forged in the absence of external support - quickly consolidated control throughout the country, ushering in a period of growth and institutional reformation that is almost unparalleled in Africa's postconflict countries. Indeed, on the economic front, per-capita GDP growth soared after Museveni's victory, and remained impressive throughout the 1990s. National economic growth has very substantially contributed to the reduction of poverty. By 1997, the average income of Ugandans had increased by two-fifths in the space of a decade. In 2000, a household survey

\footnotetext{
${ }^{49}$ It is important to recognize that the evidence presented here advances a causal proposition, but is not a rigorous test of its validity. I have explicitly selected on the dependent variable - that of non-intervention and state-building - to spell out the links between war-making and institutional development. Future research might focus on testing the conditions under which non-intervention leads to state-building by looking at cases of failed recovery, where the international community also did not intervene, as well.

${ }^{50}$ Paul Collier, “The Challenge of Ugandan Reconstruction,” The World Bank,1999, p. 1.

${ }^{51}$ Ibid., p. 2.
} 
revealed that the share of the country's population living in poverty had dropped from $56 \%$ to $35 \%$ in just eight years. ${ }^{52}$

\section{(Insert Graph 1)}

Uganda's economic success rivaled that of the best-performing developing countries in the 1990s. And the story typically told of this dramatic transformation - from failed state to emerging market - is one of donor-induced policy reform. Museveni followed the standard structural adjustment prescriptions of controlling public spending and devaluing the exchange rate in order to boost exports. He liberalized the coffee market, making it possible for coffee farmers to retain most of their export proceeds, leading to a boom in the market. Museveni tamed inflation, accumulated foreign exchange reserves, and even cut the civil service in advance of an election. In this period, foreign aid poured into Uganda as donors circled around in support of an African success story.

But Sebastian Mallaby, in a new biography of World Bank President James Wolfhenson, argues that Uganda's success was not so much a product of aid-induced policy reform, but rather "the less fashionable truth... it reflected the influence of an enlightened autocrat." "53 The ownership of policy reform that was the hallmark of Uganda's experience resulted from harddriving Ugandan technocrats who pushed the World Bank and IMF to transfer resources and autonomy to policymakers in Kampala rather than Washington. Aid conditions helped the Ugandan government implement difficult reforms in the early stages, but the good institutions that supported a consensus in favor of policy reform were homegrown.

And it is the transformation of these institutions that is perhaps the most impressive product of Museveni's victory. ${ }^{54}$ The most striking example of Uganda's institutional reshaping occurred at the village level. ${ }^{55}$ Forged during the civil war under the rubric of "popular democracy,” the NRM established Resistance Councils (RCs) in every village. In establishing the RCs, the NRM brought together all adult residents of a village to elect a council which would have the power to decide on local issues and resolve local disputes. The NRM used the RC system to enlist sympathetic civilians in organizing food, recruits, and intelligence for the war effort. $^{56}$ Resistance councils were also established at successively higher levels, from the village up to the district. Post-1986, the NRM extended the reach of the RC system - later called Local Councils (LCs) - into every village in Uganda. Fiscal decentralization which began with the Local Government Act of 1997 provided the new system with an infusion of resources and renewed authority designed to strengthen its influence at the local level and make it a more

\footnotetext{
52 Sebastian Mallaby, The World's Banker: A Story of Failed States, Financial Crises, and the Wealth and Poverty of Nations (New York: Penguin, 2004).

53 See Mallaby, The World's Banker, Chapter 8.

${ }^{54}$ Nelson Kasfir, “No-party Democracy in Uganda,” Journal of Democracy Vol. 9, No. 2 (1998), p. 1.

55 J. Oloka-Onyango, “New Breed Leadership, Conflict and Reconstruction in the Great Lakes Region of Africa: A Sociopolitical Biography of Uganda’s Yoweri Kaguta Museveni,” Africa Today (2003), p. 29-52.

${ }^{56}$ See Ondoga Ori Amaza, Museveni’s Long March from Guerrilla to Statesman (Kampala: Fountain, 1998).
} 
formal part of the government. ${ }^{57}$ Importantly, the RCs represented a transformation in the local government structure, replacing chiefs and male elders with elected local representatives. ${ }^{58}$

After its victory, the NRM government also launched a participatory constitution-writing process that engaged the masses in the design and writing of the constitution. Compared to similar efforts in other countries, Uganda's process was "the most extensive in the types of participation it employed, the scope of inclusion, and the time period allowed for public participation." 59 In the first phase, the Ugandan Constitutional Commission held eighty-six district and institutional seminars to elicit views on the agenda and the process; developed educational materials for and held seminars in all of the country's 813 sub-counties; received and reviewed 25,547 memoranda from individuals and groups; examined foreign constitutions; and prepared a preliminary draft of the constitution. ${ }^{60}$ In the second phase, Ugandans elected a nation-wide Constituent Assembly (CA) that sat for sixteen months of intensive debate before a final constitution was passed in 1995. The election of the CA was the founding national election of the NRM, and with $87 \%$ turnout, it represented a sharp break from past periods of instability and exclusion. It complemented the democratic decentralization inherent in the RC system, and brought the new ethos of engagement to national-level politics as well.

The most controversial aspect of Uganda's institutional reshaping has been the advent of a system of no-party democracy. ${ }^{61}$ Although parties were legalized again in 2004, nearly two decades of NRM governance have been characterized by the absence of political party competition. Instead, all adults, by virtue of residence, are members of the Movement and elections are held at every level to select candidates on the basis of personal merit rather than political affiliation.

While it is easy to view the Movement system as nothing more than a special form of authoritarianism, such a casual view misses the underlying institutional transformation envisioned by the NRM leadership. During the guerrilla war, Museveni articulated a critique of Ugandan politics that centered on the tendency of political party competition to exacerbate sectarian tendencies, leading to conflict and undermining democracy. The NRM, by contrast, sought to build a "broad-based" government in order to bring these distinct groups together. This process began during the guerrilla war as Museveni and the leaders of the Movement, who were largely Banyankole, developed a political strategy that appealed to a broad diversity of ethnic groups throughout the center and south of the country. Museveni had little choice in this respect as his ethnic group was much too small to support the building of a capable and effective

\footnotetext{
57 Tarsis Kabwegyere, People’s Choice, People’s Power (Kampala: Fountain, 2000).

${ }^{58}$ See Expedit Ddungu, "Popular Forms and the Question of Democracy: The case of Resistance Councils in Uganda,” Centre for Basic Research Publications No. 4, Kampala, 1989. Kabwegyere, People’s Choice, People’s Power, also reviews the body of evidence on how RCs have worked in practice.

${ }^{59}$ See Devra Coren Moehler, “Public Participation and Support for the Constitution in Uganda,” Unpublished Manuscript, Cornell University, 2004.

${ }^{60}$ Coren Moehler, “Public Participation and Support for the Constitution in Uganda,” p. 9.

${ }^{61}$ See Kasfir, “No-party Democracy in Uganda.” In a more recent review of the situation, Tripp expresses growing reservations about the increasingly authoritarian nature of the Museveni regime. See Aili Mari Tripp, "The Changing Face of Authoritarianism in Africa: The Case of Uganda,” Africa Today (2004), p. 3-26.
} 
guerrilla army. The strategy of inclusiveness continued when the NRM took power. Museveni appointed opponents of all political stripes to high posts in government and expanded the army dramatically to incorporate most of military competitors for power. Although the broad-based structure of the Movement has weakened considerably over time, the idea of continuing to restrict party competition received an electoral mandate with a nationwide referendum in 2000.

The Movement system is not without its faults. Northern Uganda remains mired in a conflict that has terrorized civilians almost since Museveni came to power. Political party competition continues to face significant restrictions, and the President is toying with a constitutional change that would allow him to serve a third term. Nonetheless, Uganda must be taken seriously as a critical example of successful post-conflict recovery in Africa. Its recovery has involved the design and construction of institutions of government that generate economic growth, empower the citizenry, and help to constrain the machinations of the political elite. Perhaps, most importantly, the origins of these institutions lay in the guerrilla war itself as Museveni designed the RC system to finance and support his mobile army, institutionalized deliberative processes to generate political support, and constructed a broad-based Movement capable of drawing in members of other ethnic groups so that he could win and consolidate power nationwide.

\section{The Benefits of Secession}

As in Uganda, Eritrea's economic and political transformation followed the accession to power of a rebel group, the Eritrean People's Liberation Front (EPLF), which managed to secure what no other group in Africa had done in the post-colonial period - secession from a sovereign state. Borne of an internal guerrilla struggle, waged in the absence of external support, the EPLF took the capital city of Asmara in 1991, in broad daylight without a single shot being fired. The soldiers of the Ethiopian army, demoralized after decades of warfare, laid down their arms as EPLF units marched into the city. Over the next two years, the Provisional Government of Eritrea (PGE/EPLF) established a cordial and cooperative relationship with the Transitional Government of neighboring Ethiopia (TGE). In 1993, a UN-sponsored referendum was held in which $99.81 \%$ of the population voted for independence in a free and fair election.

Rebel victories in Eritrea and Ethiopia brought Africa's longest-running war to a surprisingly smooth ending. During more than thirty years of fighting - a war reminiscent in size and scope to that now taking place in Sudan - Eritrea experienced a human tragedy of immense proportions. $^{62}$ Estimates suggest that more than 250,000 civilians were killed in Eritrea alone. More than one-third of the population left the country, seeking refuge elsewhere in the region, or in Europe and North America. Those who remained in the country during the war experienced a large-scale disruption in social services, particularly in the areas of health and education. By the end of the war, the adult illiteracy rate was as high as $80 \%$ and life expectancy at birth among the lowest in Africa. And Eritrea's physical infrastructure was in a state of ruin; roads were impassable, bridges were destroyed, the railroad had been uprooted by the

\footnotetext{
${ }^{62}$ Berhane Woldemichael and Ruth Iyob, "Reconstruction and Development in Eritrea: An Overview," in Martin Doornbos and Alemseged Tesfai, Post-Conflict Eritrea: Prospects for reconstruction and development (Lawrenceville, NJ: The Red Sea Press, 1998).
} 
Ethiopians, and power generation capacity was severely depleted. When the EPLF took power, it inherited a country in economic ruin and a population devastated by decades of violence.

Slightly more than a decade later, Eritrea has made tremendous strides toward economic stability, growth, and political transformation. Its steps have been deliberate and pragmatic shaped by the legacy of the EPLF's self-reliance during the guerrilla war - evidence of an "ownership" of policy reform distinct from that in most African countries.

Eritrea experienced strong economic growth and macroeconomic stability in the years immediately following independence. ${ }^{63}$ From an annual average contraction in GDP of over 1 percent per year between 1985 and 1993, GDP grew at an average of 7 percent during 1994-97, one of highest rates in Africa. ${ }^{64}$ Inflation was reduced from 11 percent in 1995, to just under 1 percent in 1997, the fiscal deficit from 22 percent of GDP to 6 percent over the same period, and tax revenues rose from 12.4 percent of GDP to 16 percent in only give years. Social service delivery - a key priority of the new government - improved remarkably as well. Public expenditures to health and education rose significantly and Eritreans began to see results as illiteracy fell from 55 percent to 47 percent, within six years of independence, and infant mortality dropped from 72 to 61 per thousand, putting Eritrea well below the average of SubSaharan Africa.

Eritrea's progress on the economic front might have continued uninterrupted were it not for the escalation of a border dispute with Ethiopia into full-scale war in $1998{ }^{65}$ When hostilities ended in 2000, Eritrea had once again been destroyed: more than 1.1 million people had been driven from their homes, agricultural production had collapsed, and direct war damage amounted to 90 percent of 1999 GDP. ${ }^{66}$ While a national reconstruction program is underway and economic growth returned to 3.0\% in 2003 - Eritrea faces significant challenges as it attempts to restructure its economy away from a dependence on Ethiopian transshipment revenues.

Like Uganda, the institutional transformation of Eritrean politics, with its roots in the guerrilla struggle, is most revealing. A democratic decentralization of political power, a participatory constitution-making exercise, and the building of national political institutions reflective of a new national identity were all remnants (and products) of the EPLF's war-making effort. And the transformation has been so complete that by 2003, noted writer Robert Kaplan would describe Eritrea as, "newly independent, sleepily calm, and remarkably stable,” with “a

\footnotetext{
${ }^{63}$ See Economist Intelligence Unit, “Eritrea Country Profile 2004,” p. 20. Also see Operations Evaluation Department, “Eritrea: Country Assistance Evaluation,” The World Bank, Report No. 28778, April 2004.

${ }^{64}$ See Operations Evaluation Department, “Eritrea: Country Assistance Evaluation,” The World Bank, Report No. 28778, April 2004.

${ }^{65}$ The destruction experienced by Eritrea in the aftermath of its border war with Ethiopia suggests that Tilly's formulation should not be interpreted too broadly. The war-making process generates effective state institutions under a set of limited conditions - when groups or states face a significant threat to their survival, a domestic revenue imperative, and few external resources to minimize the costs of mounting war. But this does not mean that war always produces economic growth and democracy and consolidates the power of states.

${ }^{66}$ Ibid., p. 2.
} 
surprisingly functional social order” and an impressive “degree of non-coercive social discipline."67

Soon after independence, the Eritrean government initiated a massive overhaul of the local government structure to support efforts to consolidate national unity and maintain aspects of participatory democracy forged during the war. Its first step was to redraw provincial lines, rejecting the old administrative boundaries - loosely based on ethnicity and kinship - used by colonial powers in a policy of divide and rule. ${ }^{68} 10$ provinces, or awrajas, were replaced by six new administrative regions, zoba, and sub-regions, that criss-cross ethnic and kinship boundaries. Iyob argues that, "this ethnic scrambling may not eliminate such animosities as exist, but it is hoped that they can forestall segregationist tendencies and, coupled with the regime's socio-economic initiatives, redirect ethnic energies to national construction.”69

The new Eritrean government also reformed structures of local government. During the liberation war, the EPLF constructed a system of popular democracy in which elected peoples' assemblies (baito) worked closely with EPLF cadres in district and village-level decisionmaking. $^{70}$ At the province level, baitos were formed - with a majority of representatives elected from the districts and a minority appointed by the EPLF - and operated as quasilegislative bodies. ${ }^{71}$ After liberation, this system was introduced throughout the country, and supported by local and regional elections in 1992-93.

With the restructuring of administrative boundaries, the new Eritrean government took advantage of the opportunity to reshape the popular democratic structures created during the war, in line with the objectives of consolidating national unity and implementing national-level policies. While elected people's assemblies were discontinued at the local level, the government introduced meetings of the whole village community, megaba'aya, to advise centrally-appointed administrators who act as liaisons to the executive branch in Asmara.

When the EPLF came to power, it also initiated a participatory constitution-making exercise which sought to engage the masses in the design of a stable, widely accepted framework for the governance of Eritrea. ${ }^{72}$ The EPLF rejected the option of adopting previously existing constitutional texts and launched a three-year consultative period for the drafting of a constitution. As in Uganda, participation in the process of writing the constitution was fundamental to the EPLF's state-building effort. Building on its legacy of grassroots

\footnotetext{
${ }^{67}$ Robert Kaplan, “A Tale of Two Colonies,” The Atlantic Monthly (April 2003), p. 46-53.

${ }^{68}$ Iyob offers a broad overview of the legal-institutional steps taken by the EPLF to give structure to the newly independent state. See Ruth Iyob, “The Eritrean Experiment: A Cautious Pragmatism,” The Journal of Modern African Studies Vol. 35, No. 4 (December 1997), p. 647-73.

${ }^{69}$ Iyob, “The Eritrean Experiment,” p. 655.

${ }^{70}$ For an in-depth review of the EPLF's guerrilla struggle for the independence of Eritrea, see Dan Connell, Against All Odds: A Chronicle of the Eritrean Revolution (Lawrenceville, NJ: The Red Sea Press, 1993).

${ }^{71}$ Alemseged Tesfai, "Issues of Governance in the Eritrean Context," in Martin Doornbos and Alemseged Tesfai, Post-Conflict Eritrea: Prospects for reconstruction and development (Lawrenceville, NJ: The Red Sea Press, 1998).

${ }^{72}$ Pool offers a valuable history of the EPLF and its transformation into the ruling party of Eritrea. See David Pool, From Guerrillas to Government: The Eritrean People's Liberation Front (Oxford: James Currey, 2001).
} 
mobilization in the liberation war, the government invested in political education and information seminars in rural communities across the country, and moderated serious political debates in the urban centers. ${ }^{73}$ The constitution that was adopted provides the basis for participatory democracy by establishing social and economic bases for equal citizenship and participation across ethnic, regional, religious, and gender groups. This emphasis on equality had been a hallmark of the EPLF's mobilization during the liberation war and it became fundamental to the constitutional order adopted after independence.

The design of Eritrea's national political institutions also reflects the EPLF's unflinching focus - forged during the war - on maintaining a national identity that supersedes ethnic, regional, and religious divisions. Hence the decision to ban political parties based on ethnicity and religion. The country's leaders viewed a no-party system as the best way to counter divisive ethnic and sectarian political tendencies that might undermine the transition. The EPLF was transformed into the People's Front for Democracy and Justice (PFDJ), and by mid-1996, the PFDJ had over 1000 local branches and more than 600,000 members, a figure approximating most of Eritrea's adult population. ${ }^{74}$ While Eritrea's legislative and executive branches were virtually indistinguishable from the Front in the first years after independence, gradual steps have been taken to separate the two. Issayas Afeworki, the leader of the EPLF, became the head of state during the transitional period, and his role was formalized after independence, as the constitution affirmed that Eritrea's leaders would be selected by the national assembly, rather than a direct vote of the people. The dominance of the EPLF as a mass party mirrors the role of the Movement in Uganda and challenges standard views of multi-party democracy as the desired outcome to promote a stable peace and robust development.

While the EPLF/PFDJ has produced enormous benefits for the Eritrean people, it is difficult to ignore some key warning signs. The devastating war with Ethiopia, which undermined much of the progress made up to that point, and the increasing constraints imposed on a growing chorus of opposition voices, signal that the broad consensus underlying the Eritrean transition may be breaking down. These tendencies to fight wars and preserve the remnants of the mass party - two characteristic behaviors of leaders that emerge from processes of autonomous recovery - might be seen as potential costs of non-intervention, but costs that must be weighed against the benefits, a task we will undertake in the final section.

\section{State Structures Out of Anarchy}

A review of the situation in Somalia offers one final look at how autonomous recovery works in practice. But while Uganda and Eritrea offer examples of state consolidation following a rebel victory, the situation in Somalia reflects the construction of institutions - even sub-states - out of a situation of statelessness.

No country has epitomized the conflict trap more than Somalia, which has gone without a functioning central government since 1991. Somalia has also been home to numerous external attempts to rebuild the state; without exception, they have failed. Few Americans will forget the

\footnotetext{
${ }^{73}$ Iyob, “The Eritrean Experiment,” p. 656.

${ }^{74}$ Pool, From Guerrillas to Government, p. 177.
} 
downing of a Black Hawk helicopter in 1993, which spelled the end of an American-led effort to stabilize Somalia. Between 1993 and 1995, the UN Operation in Somalia (UNOSOM) mobilized significant manpower and financial resources for a peace-enforcement operation that never succeeded in building an operative central government. Since the collapse of the central government, the international community has sponsored fourteen rounds of peace talks in just thirteen years. The Arta process, in 2000, produced the Transitional National Government (TNG), which was virtually defunct within two years. Just this year, in Kenya, a Transitional Federal Government (TFG) has been formed, but nearly four months later it still has failed to establish a foothold in the country.

With its absence of a central government, Somalia has been viewed as a country in a state of protracted anarchy. The dominance of warlords and the continuation of violence are assumed to have continued without interruption throughout the post-1991 period. A closer look, however, reveals a process of institutional change and development orchestrated by local actors with little support from the international community. Indeed, a renowned expert on Somalia concludes that, "far from sinking into complete anarchy, Somalia has seen the rise of sub-state politics, some of which have assumed a fragile but nonetheless impressive capacity to provide core functions of government."75

Somalia's hallmarks of institutional change and development are the breakaway states of Somaliland and Puntland. These regional polities have emerged independent of a cumulative state-building effort and reflect locally-driven efforts to "establish cooperative, predictable, and lawful relationships between clans, usually in order to promote commerce."76 They have developed in fairly homogenous regions, where one clan wields sufficient power to impose its will on minority populations. But surprisingly, the new state structures have not become simple tools for domination by one group. Both regional governments have made significant advances in building administrative capacity and opening the doors to democratic practices.

Despite the unwillingness of the international community to offer recognition, Somaliland has made remarkable progress since it declared its independence in 1991. Indeed, April 2003 marked, in the words of the International Crisis Group, "an experience all too rare in the Horn of Africa."77 Voters went to the polls to participate in an election without a predetermined outcome. While the incumbent was reelected, his victory was a surprise. He won by only 80 votes out of nearly 500,000 cast; he is not a member of Somaliland's majority clan and; most believed that the opposition would win. The presidential election was Somaliland's second election since 2002, after nearly 32 years without one.

\footnotetext{
${ }^{75}$ Given its volatile recent history, few researchers have been able to get inside Somalia to conduct fieldwork on issues of political stability and violence. Menkhaus has continued to conduct research within Somalia on a regular basis, and offers provocative conclusions about the nature of governance within the country in a recent paper. See Ken Menkhaus, Somalia: States Collapse and the Threat of Terrorism, Adelphi Paper 364 (Oxford: Oxford University Press, 2004), p. 11.

${ }^{76}$ Menkhaus, Somalia: State Collapse and the Threat of Terrorism, p. 25.

${ }^{77}$ Much of the recent writing on Somalia comes from conflict-monitoring non-governmental organizations. For example, see International Crisis Group, “Somaliland: Democratisation and its Discontents,” July 28, 2003, p. 1.
} 
These bold steps toward democratization are a critical part of a more than decade-long effort to construct a functioning central state for the breakaway region. Following its declaration of independence, Somaliland embarked on a period of relative political stability and economic growth. $^{78}$ More than 500,000 people have returned to their homes, tens of thousands of dwellings and businesses have been rebuilt, and the majority of local militias have been demobilized and incorporated into the national armed forces. ${ }^{79}$ The government has been able to restore basic social services, and the private sector has grown, fueled by the livestock trade and remittances that arrive from overseas. With few significant sources of foreign aid, the government has delivered basic civil administration over roughly 80 percent of the territory, a disciplined army and police force, and a relatively stable currency - successes that cannot be undervalued in such a volatile region. ${ }^{80}$

On the political front, Somaliland's democratization has resulted from a long, internal struggle. The International Crisis Group suggests that, "Somaliland's international isolation -

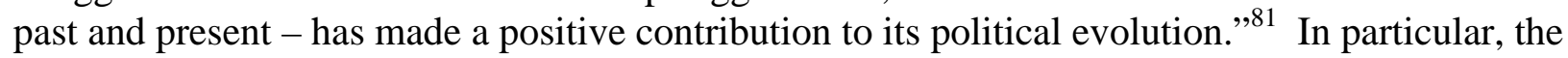
Somali National Movement (SNM) - formed in 1981 to overthrow the Barre regime in Mogadishu - was unable to obtain international sponsorship for its guerrilla struggle, instead turning to the domestic population to build a popular base of support. The SNM, which was dominated by the majority Isaaq clan, played a key part in the fall of the Barre regime, but then quickly turned its attention to Somaliland, where it consolidated control and formed a transitional administration. ${ }^{82}$

A 1993 national conference in Boorama, which involved hundreds of representatives meeting over five months, signaled the first, important step toward replacing the factional rule of the SNM with a representative civilian administration. The conference established the beel system, a hybrid of Western political institutions and a Somali system of clan representation, which provided for seats in the Parliament to be distributed by clan. In subsequent years, Somaliland's government supported the development of a permanent constitution which enshrined the representative system; put that new constitution to a national referendum, in which 97 percent endorsed it; survived the death of an incumbent president in 2002, after which the Vice President, from a minority clan, was elevated to the Presidency; and launched nationwide local elections that entrenched democracy by decentralizing government authority throughout the

\footnotetext{
${ }^{78}$ Somaliland had a previous brush with independence, following the end of British rule in 1960. It subsequently elected to join in a union with the Italian-administered UN-Trusteeship of Somalia.

${ }^{79}$ Mohamud Jama, “Somalia and Somaliland: Strategies for dialogue and consensus on governance and democratic transition,” Paper prepared for the UNDP Oslo Governance Centre, January 2003.

${ }^{80}$ The International Crisis Group estimates that Somaliland received approximately \$15 million in foreign aid (with administrative costs deducted) although all funding has been directed through international aid agencies, rather than the government. Assistance cannot be provided directly to a government the international community does not recognize. International Crisis Group, “Somaliland: Democratisation and its Discontents,” p. 7.

${ }^{81}$ Ibid. p. 8.

${ }^{82}$ While the case of Somaliland does not involve a rebel victory giving rise to institutional change, the dissolution of Somalia and the organization of a guerrilla movement, the SNM, to protect the interests of Somaliland in the midst of the fighting is suggestive that war-making at least laid the foundations for the state in the breakaway republic. The subsequent bargains that were struck with other clans in the design of the transitional government did not evolve directly out of military conflict within Somaliland, but instead out of the imperative to provide law and order.
} 
country. Indeed, Somaliland's success - in administration and representation - has provided a positive example for the rest of the country.

Puntland, while not yet opting for independence like Somaliland, has also experimented with efforts to build a sub-national government characterized by substantial autonomy. A clear aim has been to establish a regional state within a broader Somali framework, federal or otherwise, which has yet to be developed. This building-blocks approach to the reformation of a central Somali state runs directly counter to traditional strategies of state-building in post-conflict countries. Yet by 1999, UN agencies were already concluding that the "emergence of Puntland potentially represents a viable form of political development" and that doubts about the formation process "should not be allowed to influence the overall attitude of donors and other external actors." 83

As a potential sub-state, Puntland has a number of advantages. ${ }^{84}$ Across the three regions that constitute its territory, most of the population belongs to a single sub-clan, the Majeerteen. Economically, the three regions are also complementary, with the economy built around the livestock trade and the export of frankincense and fisheries. Third, the three regions developed a cooperative working relationship since 1991, under the unofficial political leadership of the Somali Salvation Democratic Front (SSDF), the main military force in the northeast. The SSDF has provided a political umbrella for contacts between the three regions, and the military manpower to protect the strategic port of Boosaaso, especially when it came under threat from a radical Islamist group in 1991.

Before 1998, initial attempts at building administrative structures in Puntland operated independently at the regional level in Bari, Nugal, and North Mudug. ${ }^{85}$ A shift toward interregional administration offered the three regions a number of benefits. Previous attempts at administration had foundered either because governments were unable to arrange a steady flow of revenue, or because the governments were unable to maintain full control over the security arrangements necessary for full taxation to take place. ${ }^{86}$ In particular, few traders were willing to be taxed at administration checkpoints in each region and at unauthorized checkpoints along the way. Political elites came to realize that the collection of full revenues from transit associated with the Boosaaso seaport depended on the government's ability to maintain authorized checkpoints and remove unauthorized ones - something that required a capacity to project force.

In 1998, representatives of the three regions met over three months to deliberate on the structure of an inter-regional administration. That July, the conference declared the formation of a Puntland state as a sub-unit of a future federal Somalia. The group adopted a constitution and

\footnotetext{
${ }^{83}$ United Nations Development Office for Somalia, "The Puntland State of Somalia: Steps toward Good Governance,” January 1999, p. 1.

${ }^{84}$ See Martin Doornbos, “Somalia: Alternative Scenarios for Political Reconstruction,” African Affairs 101 (2002), p. 101.

${ }^{85}$ United Nations Development Office for Somalia, "The Puntland State of Somalia: Steps toward Good Governance,” p. 7-9.

${ }^{86}$ Ibid., p. 21.
} 
appointed a president and prime minister. Colonel Abdullahi Yusuf, former SSDF Chairman, was elected the president, and his government was supported by a nine member Cabinet and 69member Parliament, reflective of the different interests in the three regions. Not surprisingly, the first act of the Puntland government was the installation of a unified police force which sought to clear the main highway of armed militia and illicit checkpoints. ${ }^{87}$

While the breakaway regions of Somaliland and Puntland offer the best evidence of state formation in Somalia, progress is being made even in Mogadishu, again in the absence of external intervention. The British Broadcasting Corporation (BBC) recently reported on the mechanics of water provision in some Mogadishu neighborhoods, where a private supplier, the Isaf Water and Electricity Supply Company, pipes treated water from a bore hole to more than 800 families. ${ }^{88}$ Three phone companies are engaged in fierce competition for both mobile telephone and landline customers; unconstrained by state intervention, prices are lower than in many neighboring countries. In Mogadishu, it takes just three days for a landline to be installed! ${ }^{89}$ Entrepreneurs are providing electricity without a functioning central grid; cities have been divided into manageable quarters and electricity is provided using secondhand generators. Despite the absence of law and order and a functional court system, bills are paid and contracts enforced through local clan-based dispute resolution mechanisms. ${ }^{90}$

Across southern Somalia, the most important level of politics is at the municipal and neighborhood level where coalitions of clan elders, intellectuals, businessmen, and Muslim clergy are establishing mechanisms to maintain local control. ${ }^{91}$ Fundamental to this structure are sharia courts which have been widely embraced by local communities as means to restore the rule of law. The courts have tended to be run by traditional, moderate elements and mainly police relationships within clans, although they also facilitate interactions across clan boundaries. Many of these local administrations are beginning to develop an administrative capacity as well, partnering with local entrepreneurs to deliver basic services. And much of the pressure for order comes from local businessmen, whose commercial ties "transcend clan and conflict," and create a powerful incentive for the development of increasingly centralized forms of governance.

Importantly, while processes of autonomous recovery have contributed to the emergence of functional institutions in Somalia, external pressure to rebuild a centralized state has only led to renewed violence. "The revival of a state structure," Menkhaus concludes, "is viewed in Somali quarters as a zero-sum game, creating winners and losers in a process with potentially high stakes." 92 The first incarnation of a brokered central government in 2000, the TNG, sparked new rounds of fighting as clans and political elites battled for influence in the new government and the continuing external dialogue. Indeed, after 1995, Somalia no longer exhibited casualty

\footnotetext{
${ }^{87}$ For a more in-depth review of the internal process of state-building in Puntland see WSP Somali Program, Rebuilding Somalia: issues and possibilities for Puntland (London: HAAN Associates, 2001).

${ }^{88}$ Joseph Winter, “Somalia’s Angels of Mercy,” British Broadcasting Corporation, December 1, 2004.

${ }^{89}$ Joseph Winter, “Telecoms thriving in lawless Somalia,” British Broadcasting Corporation, November 19, 2004.

${ }^{90}$ Tatiana Nenova, Private sector response to the absence of government institutions in Somalia,” The World Bank, July 2004.

${ }^{91}$ Menkhaus, Somalia: State Collapse and the Threat of Terrorism, p. 26.

${ }^{92}$ Ibid., p. 18.
} 
levels high enough to qualify as a civil war, until the TNG attempted to consolidate control and failed in 2002. It is still too early to assess the progress of the new TFG, but if the past is any indication, external efforts are likely to undermine the functioning set of institutions that are beginning to take shape in many corners of "lawless" Somalia.

\section{THREE TRADEOFFS}

While the preceding section does not attempt a test of the theory of autonomous recovery, it nonetheless offers evidence in favor of its plausibility. In particular, the statistical evidence is unequivocal: wars that end in military victory produce more stable post-war regimes. Moreover, the case studies of Uganda, Eritrea, and Somalia draw out the links between war-making and state-making and demonstrate that - when groups or states face a significant threat to their survival, a significant domestic revenue imperative, and have few external resources to reduce the costs of war - conflict itself can give rise to functional, representative, and self-sustaining institutions of government.

Autonomous recovery thus represents a form of state-building that can and should be compared and contrasted with other forms of intervention and post-conflict reconstruction. Figure 1 offers a first cut at arraying various forms of state-building now employed by the international community. Forms of intervention are characterized by the extent to which they generate administrative capacity and legitimacy for post-conflict governments. A government's capacity and legitimacy can be provided by external sources, such as international aid agencies or the UN Security Council, come from internal sources, such as warring factions or political movements, or evolve from some combination of both.

\section{(Insert Figure 1)}

Looking at state-building efforts from this perspective reveals some interesting patterns. First, most available strategies rely on external mechanisms to generate legitimacy and capacity for interventions and the post-conflict governments they support. Legitimacy tends to come from UN Security Council mandates which authorize international actors to negotiate agreements between political elites or to return a government to power. Capacity is provided by the massive influx of international aid agencies that quickly take over the tasks of delivering social services, while beginning efforts to reconstruct national and local governments in the aftermath of war.

Second, autonomous recovery is the only form of state-building that combines domestic sources of legitimacy and capacity in the construction of functional governments. War-making is a process that can provide strong incentives for competing groups to secure the consent of the governed, overcome sectarian tendencies in favor of more national identities, and develop the administrative capacity required to deliver public goods to their constituents.

How should policymakers weigh intervention against non-intervention? In this section, I spell out a number of tradeoffs that policymakers may face in thinking about intervention. Importantly, the tradeoffs enumerated here are quite different than those typically discussed when debating whether the international community should intervene. Here, I focus on the 
tradeoffs for the country on the receiving end of the intervention, rather than for the nations spending blood and treasure to bring these conflicts to an end.

\section{Tradeoff \#1: Minimizing Loss versus Maximizing Institutional Capacity}

Even if external intervention proved entirely incapable of standing up effective governments in the aftermath of conflict, many would argue for its importance based on much shorter-term considerations. International efforts can bring at least a temporary stop to the killing of civilians, mass rape, the destruction of infrastructure, forced displacement, and the spread of malnutrition and disease that tend to accompany civil war. The international community's failure to intervene in Rwanda allowed more than 800,000 civilians to be slaughtered. Inaction in the face of the current crisis in Darfur is contributing to the deaths of tens of thousands more. A slow international response to fighting in Democratic Republic of the Congo in the late 1990s is partly responsible for the deaths of approximately four million Congolese from war, famine, or disease. Many constituents of developed nations are increasingly unwilling to allow such slaughter and death to take place when the resources and capacity exist to bring the killing to a stop.

Such efforts to minimize the loss of life in the short-term should be evaluated with the long-term implications of these international interventions in mind. It may be that, in some cases, the international community's actions to stop the bloodshed come at the cost of stunting an internal process of political change - one that can generate institutions capable of preserving peace and protecting freedoms in the longer-term. Absent the development of effective institutions, countries on the receiving end of these interventions are likely to find themselves in conflict again, with the loss of life resuming until the international community returns, or the war comes to an end on its own. The difficult tradeoff here may involve lives lost today in support of a long-term process of building effective states, or ceasefires that plug the violence temporarily but allow significantly more deaths to accumulate over time as countries return to conflict again and again.

\section{Tradeoff \#2: Coalitions versus Strong Victors}

Externally-driven state-building efforts tend to set in place mediated agreements that bring warring parties into power-sharing arrangements, while autonomous recovery often produces strong victors that have consolidated control over a country's territory. Both strategies have advantages and disadvantages.

Negotiated settlements that involve the temporary incorporation of fighting factions tend to postpone the underlying fight to formalize a more permanent distribution of power. While the international community is present, efforts are initiated to make permanent the separation of politics from violence. Factions are disarmed and outsiders focus on designing a free and fair electoral process to which, it is hoped, the parties will consent, both before and after the results are in. All parties with a stake in the future of the country are given an opportunity to make their 
case for leadership. The challenge is that, given the short time horizon of the intervening forces, many warring factions are simply prepared to wait out the external actors and to resume their fighting when the international community departs.

On the other hand, autonomous recovery provides strong victors that have demonstrated their capacity to capture territory and consolidate control. Victories provide conditions amenable to significant policy reform and the extension of state power. Moreover, decisive victories clarify expectations about the finality of the postwar distribution of power, and tend to reinforce the legitimacy of the winning party.

The problem is that autonomous recovery selects leaders who are good at fighting but who may or may not be good leaders in a post-war period. The examples cited above demonstrate the manifold ways in which Museveni and Afeworki used their military victories to implement far-reaching changes in the structure and practice of governance in Uganda and Eritrea. However, both leaders have also had a hand in some of the region's more devastating international conflicts. Museveni actively supported rebellion in the DRC and Afeworki played a major part in escalating a border dispute with Ethiopia into a large-scale military conflict.

And both leaders have also faced serious accusations regarding their growing undemocratic tendencies. This process of authoritarian decay reflects a breakdown of the selfreinforcing bargain each leader struck with his constituents in fighting a war. If it results simply from the unrivaled power that accrues to military victors, it would be an unfortunate but necessary outcome of autonomous recovery. But the European state-building story suggests that accountability can survive victory and prosper in its aftermath. Thus the democratic decline of Uganda and Eritrea may follow more from external factors - the flood of international assistance - that gradually undermined the revenue dependence of Museveni and Afeworki on their domestic constituents. When autonomous recovery is weighed seriously as a policy option, one must also focus on how to constrain victors in the post-war period.

\section{Tradeoff \#3: External versus Internal Incentives for Institution-Building}

A final tradeoff relates to the incentive structure provided to local political elites to construct stable, effective, and transparent institutions of government. When interventions are mounted by outside actors, the international community must rely on the standard toolbox of aid, conditionality, and sanctions to shape the behavior of local politicians. Processes of economic policy reform, democratization, and conflict management are likely to advance largely on the basis of the back and forth between politicians and external donors. The challenge is that donors are notoriously unreliable when it comes to holding domestic governments accountable for their violations of conditionality. ${ }^{93}$ There exist too many strong incentives for donors to keep on giving even if local officials are failing to implement the desired policies. The result is that aid becomes a revenue flow for governments to help maintain themselves in power, without needing to develop an effective revenue base from taxation.

\footnotetext{
${ }^{93}$ William Easterly, The Elusive Quest for Growth (Cambridge, MA: MIT Press, 2001). For a critique of aid and conditionality in Africa see Nicolas Van de Walle, Africa and the Politics of Permanent Economic Crisis, 19791999 (Cambridge, UK; Cambridge University Press, 2002).
} 
Autonomous recovery offers outside actors a different set of tools for institution-building. When local actors face a significant threat to their survival and strong domestic revenue imperative, leaders must build organizations capable of projecting force. But these organizations are expensive to build and maintain, so local actors must turn to their constituents for support. In constructing these military organizations - the building blocks of states - leaders are disciplined by powerful incentives to secure the consent of their constituencies. And the social compact that results from this bargain is one in which the governed can use their wealth to regularly constrain the behavior of those in power.

The problem for outside actors is that autonomous recovery offers little or no control over the shape of the government likely to evolve. While aid, conditionality, and sanctions provide multiple opportunities for the international community to specify how institutions should be designed and what policies should be implemented, autonomous recovery produces governments that reflect a back and forth between local politicians and local populations. Uganda, Eritrea, and parts of Somalia are less than perfect democracies - and that may be troubling for many in the United States and beyond. But their governments provide effective administration with some broadly participatory structures never before seen in most of these environments.

\section{LESSONS FOR STATE-BUILDERS}

The rash of weak, failing, and failed states that crisscrosses the developing world is a challenge to the national security - and to the collective moral consciousness - of countries in the developed world. Now, in an era of peace between the world's most powerful nations, a growing chorus calls for active multilateral efforts to end conflict and build effective, democratic states across the developing world. Two recent articles in International Security reflect this demand for state-building and offer creative approaches to addressing the international role in state reconstruction. The resolution of these governance failures, however, requires a more careful analysis of the state-building challenge, its historical precedents in Europe, and the processes that have given rise to post-conflict success in Africa.

In this article, I have suggested that the policy consensus in favor of multilateral efforts to free countries of the conflict trap rests on a key, relatively unexplored assumption. It is widely believed that countries in conflict are highly unlikely to emerge from violence on their own. I put this assumption under the microscope by describing a process of autonomous recovery through which countries emerge from conflict in the absence of international intervention.

If countries can recover from conflict in the absence of intervention - and may be able to develop effective institutions of government out of warfare - than decisions about whether to launch state-building efforts must weigh the benefits and costs of external action to the recipient countries, not just to those sending troops. How should policymakers weigh these various tradeoffs?

Of course, the right state-building strategy will vary from case to case. Both autonomous recovery and international intervention have evident strengths and weaknesses. And the strategy employed will not - and should not - always depend on how likely the various strategies are to 
contribute to institution-building. Concerns with stopping mass killing will often trump longerterm considerations.

But the literature on state formation does offer a useful guide to prospective state-builders who want to add new strategies to the menu of policy options for addressing the weakness of governments. Effective states tend to develop where groups or governments face a significant threat to their survival, where a strong domestic revenue imperative exists, and where few external resources are available to reduce the costs of providing security. This has been the story of state formation in Uganda, Eritrea, and Somalia, and it is not impossible for other countries to undergo the same process.

If one takes autonomous recovery seriously, the challenge for outsiders is to consider policies that make it more likely that war will produce peace and institutional transformation, rather than simply violence and destruction. However, the international system, as it is currently configured, makes autonomous recovery unlikely.

The reluctance of the UN to recognize secession movements seriously reduces the viability of threats to state survival. For this reason, rebel victories have offered the best hopes of internal transformation. Were it possible for groups to secede from ineffective or incompetent states, much stronger incentives for institutional reform would exist, making war a healthy competition between rebel groups and states to secure the consent of the governed. This fundamental need to rethink sovereignty and how rents accrue to sovereign states is perhaps the most important challenge facing policymakers today.

External patrons and international markets have also dramatically reduced the cost of warfare. The United States and Soviet Union funded insurgent groups and reinforced failing governments throughout the Cold War, and regional powers have now assumed that mantle. States and rebel groups also have been able to secure massive inflows of revenue from the sale of natural resources - on both licit and illicit markets. And the easy availability of weapons on the international market continues to decrease the cost of warfare worldwide. A serious commitment to state-building in the developing world will require concerted action to increase the costs of warfare - with efforts to reduce outside aid to both governments and insurgent groups, control the illicit trade and monitor the legal trade in natural resources, and reduce the supply of small arms given special priority.

But in the aftermath of genocides in Europe, Asia, and Africa, even policymakers inclined to support processes of autonomous recovery will face powerful pressure to intervene to stop the killing. The paths of institutional transformation forged in Uganda, Eritrea, and parts of Somalia offer a critical lesson nonetheless. When the UN intervenes, it would be prudent to consider new strategies for ending wars and reconstituting states. While the UN typically wraps competing parties into a negotiated settlement and power-sharing arrangement of uncertain duration, autonomous recovery produces political leaders with the demonstrated legitimacy and capacity to implement far-reaching policy reforms and institutional change. Perhaps the most practical lesson of autonomous recovery is that we must disband with the "delusion of impartial intervention" and intervene decisively on behalf of legitimate, competent military forces already on their way to victory. 
This approach to picking and sticking with winners is already making waves in the international aid industry. Indeed, the most important reform embodied in the creation of President Bush's Millennium Challenge Account (MCA), is a shift from providing aid as an incentive for policy reform to offering assistance as a reward to only those governments that have already set in place policies to protect political freedom, invest in public goods, and create the conditions for economic growth. Just as the Board of the MCA has developed a series of metrics for distinguishing good and bad performers, the international community would be wise to develop strategies useful in identifying those military actors with the legitimacy and capacity to rule in a post-conflict period before the fighting ends.

The fundamental challenge - and one on which a healthy debate is needed - is how the international community can provide assistance and support to good-performing governments or rebel groups without corrupting them. Key to the process of state consolidation is the forging of a bargain between rulers and constituents that helps to meet the revenue imperative required to provide public goods. International assistance and external support - provided during war or in its aftermath - undermines the self-sustaining nature of the compact between rulers and constituents. Its negative effects have been visible in the decline of democracy in both Uganda and Eritrea. Current instruments of conditionality and sanctions do little to promote policy reform, and they are likely to be just as weak when it comes to constraining victors.

The durable resolution of the world's civil wars will depend to a large degree on how quickly international actors incorporate the lessons of history into current strategies. To reconstitute states with governments capable of projecting power, the international community must be prepared to identify and recognize legitimate and effective governance (in whatever form it takes). And if the political change that war produces is to survive the end of the fighting, international actors must develop new approaches to both support and constrain the winners as they consolidate power in the aftermath of conflict. 
Table 1: Intervention and Non-Intervention in Africa, 1975-2000

\begin{tabular}{|c|c|c|c|}
\hline Country & War Began & War Ended & Rebel Victory \\
\hline \multicolumn{4}{|l|}{ U.N. Intervention } \\
\hline Angola & $\begin{array}{l}1975 \\
1992\end{array}$ & 1991 & No \\
\hline Chad & 1980 & 1994 & Yes \\
\hline Central Africa & 1995 & 1997 & No \\
\hline \multirow{2}{*}{ Liberia } & 1989 & 1992 & No \\
\hline & 1993 & 1996 & No \\
\hline & 1975 & Sahara & No \\
\hline Mozambique & 1979 & 1992 & No \\
\hline Namibia & 1965 & 1989 & No \\
\hline South Africa & 1976 & 1994 & No \\
\hline Rwanda & 1990 & 1994 & No \\
\hline Somalia & 1992 & & \\
\hline \multicolumn{4}{|l|}{ Non-Intervention } \\
\hline \multirow[t]{2}{*}{ Burundi } & 1988 & 1988 & No \\
\hline & 1991 & & \\
\hline Chad & 1965 & 1979 & No \\
\hline Congo Brazzaville & 1992 & 1996 & No \\
\hline \multirow{2}{*}{ Congo/Zaire } & 1975 & 1979 & No \\
\hline & 1996 & 1997 & No \\
\hline Djibouti & 1991 & 1995 & No \\
\hline \multirow[t]{2}{*}{ Ethiopia } & 1977 & 1985 & Yes \\
\hline & 1974 & 1991 & Yes \\
\hline Eritrea & 1974 & 1991 & Yes \\
\hline Kenya & 1991 & 1993 & No \\
\hline Mali & 1990 & 1995 & No \\
\hline Nigeria & 1980 & 1984 & No \\
\hline Somalia & 1988 & 1991 & Yes \\
\hline Sudan & 1985 & & \\
\hline \multirow[t]{2}{*}{ Uganda } & 1978 & 1979 & Yes \\
\hline & 1980 & 1986 & Yes \\
\hline \multirow{2}{*}{ Zimbabwe } & 1972 & 1980 & Yes \\
\hline & 1984 & 1984 & No \\
\hline
\end{tabular}

Source: Doyle and Sambanis (2000). 
Table 2: Variation in War Outcomes in Africa, 1975-2000

\begin{tabular}{|c|c|c|c|}
\hline & $\begin{array}{l}\text { Percent of Wars that } \\
\text { End in Rebel } \\
\text { Victory }\end{array}$ & $\begin{array}{l}\text { Percent of Wars that } \\
\text { Do Not Recur } \\
\text { within } 10 \text { Years }\end{array}$ & $\begin{array}{l}\text { Percent of Wars in } \\
\text { which Low-Level } \\
\text { Violence Does Not } \\
\text { Recur within } 10 \\
\text { Years }\end{array}$ \\
\hline U.N. Intervention & & & \\
\hline Yes & $\begin{array}{c}8.33 \\
(1)\end{array}$ & $\begin{array}{c}25.00 \\
(1)\end{array}$ & $\begin{array}{c}25.00 \\
(1)\end{array}$ \\
\hline No & $\begin{array}{c}30.00 \\
(6)\end{array}$ & $\begin{array}{c}46.15 \\
(6)\end{array}$ & $\begin{array}{c}23.08 \\
\text { (3) }\end{array}$ \\
\hline
\end{tabular}

Source: Author's calculations from Doyle and Sambanis (2000) 


\section{Graph 1: Uganda's Economic Trajectory}

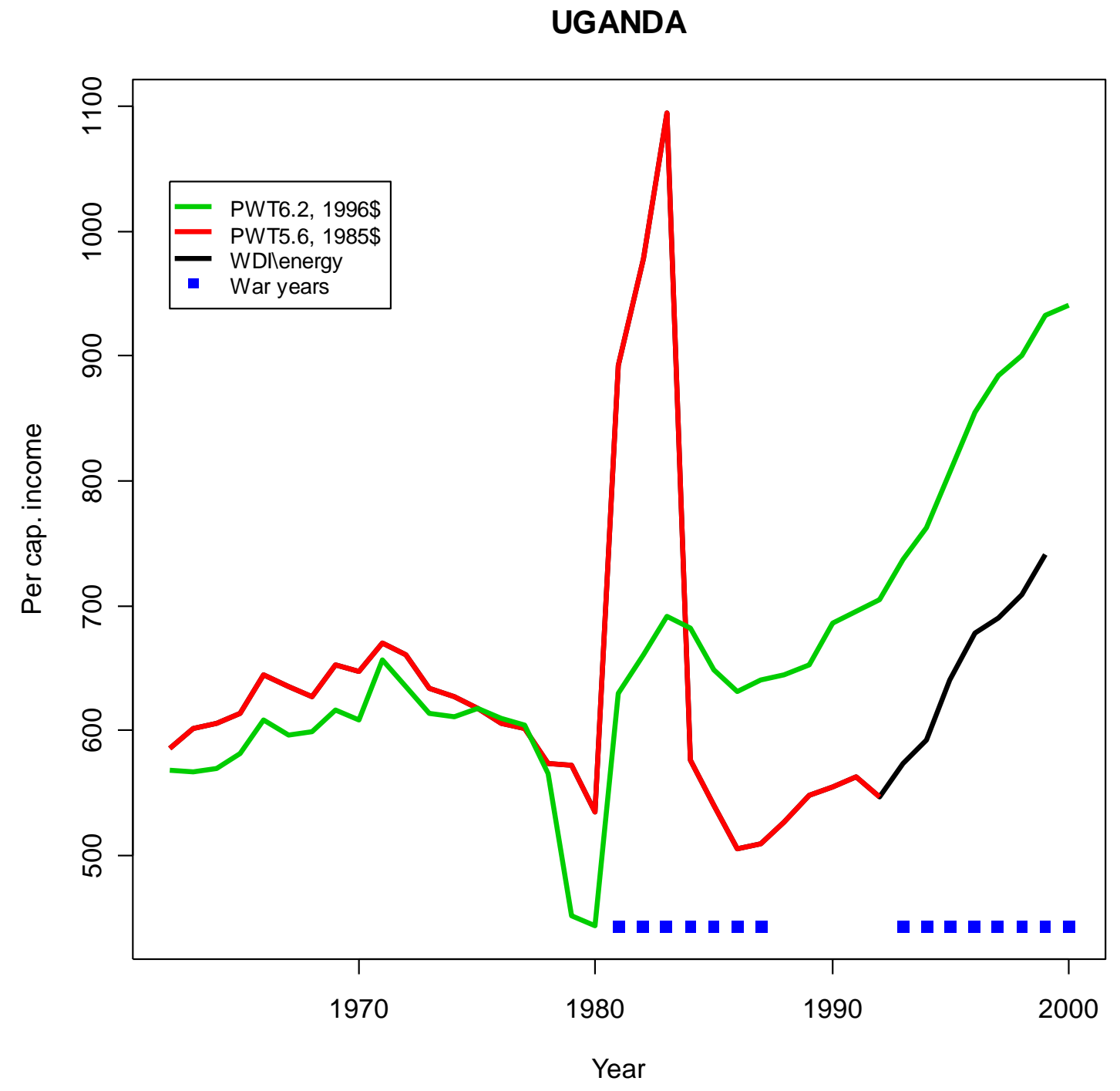


Figure 1: Forms of State-Building

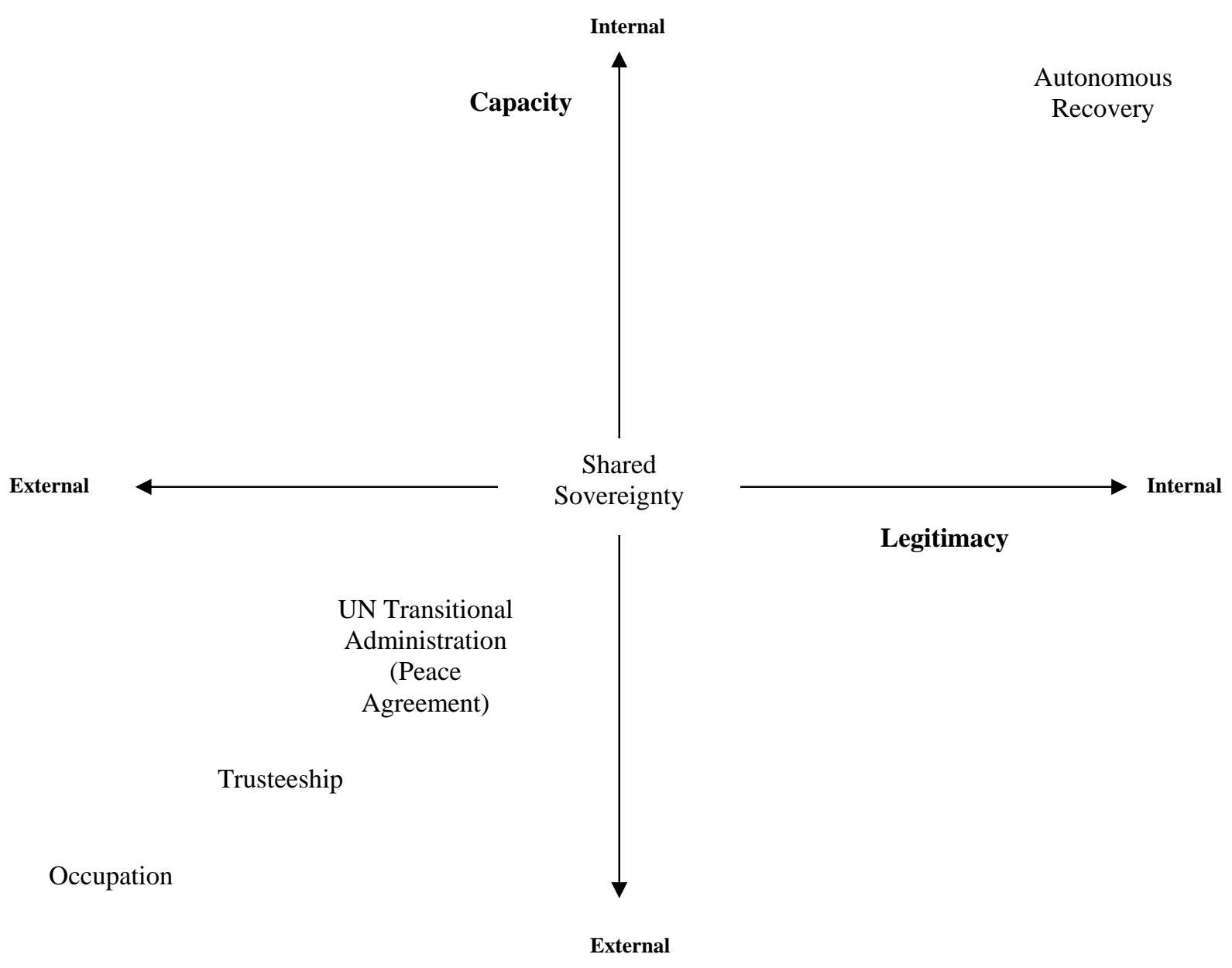

